\title{
No long-term weight maintenance effects of gelatin in a supra-sustained protein diet.
}

Citation for published version (APA):

Hochstenbach-Waelen, A., Westerterp, K. R., Soenen, S., \& Westerterp-Plantenga, M. S. (2010). No longterm weight maintenance effects of gelatin in a supra-sustained protein diet. Physiology \& Behavior, 101(2), 237-244. https://doi.org/10.1016/j.physbeh.2010.05.005

Document status and date:

Published: 01/09/2010

DOI:

10.1016/j.physbeh.2010.05.005

Document Version:

Publisher's PDF, also known as Version of record

Document license:

Taverne

Please check the document version of this publication:

- A submitted manuscript is the version of the article upon submission and before peer-review. There can be important differences between the submitted version and the official published version of record.

People interested in the research are advised to contact the author for the final version of the publication, or visit the DOI to the publisher's website.

- The final author version and the galley proof are versions of the publication after peer review.

- The final published version features the final layout of the paper including the volume, issue and page numbers.

Link to publication

\footnotetext{
General rights rights.

- You may freely distribute the URL identifying the publication in the public portal. please follow below link for the End User Agreement:

www.umlib.nl/taverne-license

Take down policy

If you believe that this document breaches copyright please contact us at:

repository@maastrichtuniversity.nl

providing details and we will investigate your claim.
}

Copyright and moral rights for the publications made accessible in the public portal are retained by the authors and/or other copyright owners and it is a condition of accessing publications that users recognise and abide by the legal requirements associated with these

- Users may download and print one copy of any publication from the public portal for the purpose of private study or research.

- You may not further distribute the material or use it for any profit-making activity or commercial gain

If the publication is distributed under the terms of Article $25 \mathrm{fa}$ of the Dutch Copyright Act, indicated by the "Taverne" license above, 


\title{
No long-term weight maintenance effects of gelatin in a supra-sustained protein diet
}

\author{
A. Hochstenbach-Waelen *, K.R. Westerterp, S. Soenen, M.S. Westerterp-Plantenga
}

NUTRIM School for Nutrition, Toxicology and Metabolism, Department of Human Biology, Maastricht University Medical Centre +, PO Box 616, 6200 MD Maastricht, The Netherlands Top Institute Food and Nutrition, PO Box 557, 6700 AN Wageningen, The Netherlands

\section{A R T I C L E I N F O}

\section{Article history:}

Received 16 September 2009

Received in revised form 28 April 2010

Accepted 4 May 2010

\section{Keywords:}

Protein

Weight maintenance

Body composition

Appetite

\begin{abstract}
A B S T R A C T
In the short-term, gelatin showed stronger hunger suppression and less energy intake compared with other proteins. This study investigated if a supra-sustained gelatin-milk protein (GMP) diet improves weight maintenance (WM) compared with a sustained milk protein (SMP) diet and supra-sustained milk protein (SSMP) diet during a 4-months WM period after 8-week weight loss (WL) in sixty-five healthy subjects $\left(28.6 \pm 3.4 \mathrm{~kg} / \mathrm{m}^{2} ; 44 \pm 10\right.$ years). Absolute protein intake was kept constant (sustained) throughout per subject. Diets were: protein(P)/fat(F)/carbohydrate(C): 15/40/45\% of energy (En\%) (SMP) and 30/25/45 En\% (SSMP or GMP) for weeks 9-16. Diets on weeks 17-24: P/F/C: 30/35/35 En\% (SMP) and 60/5/35 En\% (SSMP or GMP). From weeks 8 to 16, and weeks 16 to 24, changes in BMI were similar between the GMP $(-0.4 \pm$ 0.6 and $0.3 \pm 0.7 \mathrm{~kg} / \mathrm{m}^{2}$ respectively), and the SMP $\left(-0.7 \pm 0.9\right.$ and $0.1 \pm 0.7 \mathrm{~kg} / \mathrm{m}^{2}$ respectively) and SSMP $\left(-0.6 \pm 0.6\right.$ and $0.3 \pm 0.6 \mathrm{~kg} / \mathrm{m}^{2}$ respectively) diets. Sparing of fat free mass (FFM): increases/decreases in FFM\%/fat-mass\% from weeks 8 to 16 were similar between the GMP and both control diets, and maintained from weeks 16 to 24. In conclusion, all 3 diets resulted in a successful WM period, while a GMP diet does not improve body weight maintenance and related variables after weight loss compared with a SMP and SSMP diet.
\end{abstract}

(c) 2010 Elsevier Inc. All rights reserved.

\section{Introduction}

Obesity is associated with disorders such as hypertension, hypercholesterolemia, diabetes, and liver disease [1]. Since obesity is a major health concern and the number of people with obesity is still increasing, strategies for weight loss and weight maintenance thereafter are necessary. Therefore, short-term as well as long-term mechanisms should be affected. Recent findings suggest that an increased protein intake may serve this goal by 1 ) sustained satiety, despite similar or lower energy intake, 2) sustained thermogenesis, 3) sparing of fat free mass, and 4) lower energy efficiency during the period of weight maintenance [2-5].

In previous studies short-term effects of different protein types, represented in normal and high single-protein breakfasts/diets, on satiety, energy intake and energy expenditure were investigated [614]. Firstly, it was shown that, under 10 En\% as well as under 25 En\% protein conditions, energy intake after a single-protein breakfast was less with gelatin compared with casein, soy or whey without glycomacropeptide [8]. Under 10 En\% protein conditions, gelatin decreased hunger more than casein after a single-protein breakfast [8] as well as after a single-protein diet for one day [13]. Since gelatin is an incomplete protein, because it is deficient in certain essential amino

\footnotetext{
* Corresponding author. Department of Human Biology, Maastricht University, PO Box 616, 6200 MD Maastricht, The Netherlands. Tel.: + 3143 3881617; fax: + 3143 3670976.

E-mail address: ananda.waelen@hb.unimaas.nl (A. Hochstenbach-Waelen).
}

acids, i.e. devoid of tryptophan and imbalanced in methionine, these results may relate to a mechanism observed in metazoans, where it was discovered that the tRNA/GCN2/p-eIF2 $\alpha$ system in the brain can detect a deficiency of essential amino acids in the diet from a decline in serum amino acid levels, leading to a behavioral response that rejects consumption of imbalanced diets [15-18], and thus appears as hunger suppression. This phenomenon has been observed since the 1970 s as excesses or deficiencies of amino acids in the diet depressing food intake in rats [19]. Later, Fromentin et al. showed that the parabranchial nuclei are involved in the learned aversion to an amino acid devoid diet [20]. In a review Gietzen and Rogers explain that given a choice, herbivores and omnivores select a diet containing higher levels of protein or amino acid mixtures, even if the choices contain balanced indispensable amino acid profiles; this shows that nitrogen per se can become limiting [21]. They furthermore show that in addition to rodents, Protozoa, Nematoda, Mollusca, Arthropoda, Vertebrata including fish, birds and mammals have the same indispensable amino acids, except humans, which do not require arginine [21]. The inability of an incomplete protein diet to support human life was known already in the early 1800s, when Napoleon's injured soldiers failed to recover on a diet with gelatin as the protein source [22]. A general amino acid control system which is activated by deprivation via deacylated tRNA showed conservation of amino acid sensory mechanisms across eukaryotic species [21].

Also, when in our previous experiment, gelatin was added to the diet over $36 \mathrm{~h}$ VAS ratings on the appetite profile showed a stronger hunger suppression in comparison with casein [13], possibly through 
increased gluconeogenesis [13]. Evidence for this is given by animal model research. De novo synthesis of glucose from gluconeogenic precursors is increased by a high protein diet [23]. The main gluconeogenic organ is the liver. The activity of hepatic phosphoenolpyruvate carboxykinase (PEPCK), an enzyme involved in gluconeogenesis, is increased in rat fed a high protein diet. The satiating effect of high protein feeding could be related to the improvement of glucose homeostasis through the modulation of hepatic gluconeogenesis and subsequent glucose metabolism, glucose homeostasis and glucose signaling to the brain.

Moreover, over $24 \mathrm{~h}$ it was shown that gelatin compared with casein, under $10 \mathrm{En} \%$ as well as under 25 En\% single-protein conditions, resulted in similar effects on total energy expenditure [13]. For both protein types total energy expenditure was increased with an increased protein content of the diet [12,14]. At this moment it is not clear whether the beneficial short-term effects of gelatin on hunger and energy expenditure may play a role in the long term during a weight maintenance period after weight loss.

Since gelatin is an incomplete protein, it cannot be used as a singleprotein source in a long-term diet. To create a relatively high protein diet without lacking the essential amino acids, gelatin should be complemented with a complete protein source. Then the hunger suppression effect of gelatin being an incomplete protein may have disappeared, but a possible hunger suppression effect due to improved appetite homeostasis through gluconeogenesis still may sustain. Therefore, the aim of this study was to investigate if the addition of gelatin to a milk protein diet would improve weight maintenance during a 4-months weight maintenance period after weight loss. To investigate this during weight loss and weight maintenance, one intervention diet, a supra-sustained protein diet with gelatin and milk protein as the two protein sources in equal amounts, was compared with two control diets, a sustained and a supra-sustained protein diet with milk protein as the only protein source. The effect of the three diets on body weight (BW), body composition, respiratory quotient (RQ), resting energy expenditure, eating behavior, physical activity, postabsorptive appetite profile and relevant blood parameters were determined at the start, after 8 weeks and after 16 weeks of the weight maintenance period following weight loss.

\section{Methods and procedures}

\subsection{Subjects}

Eighty-one subjects aged 18-65 years with a body mass index (BMI) of $\geq 25 \mathrm{~kg} / \mathrm{m}^{2}$ were recruited by advertisements on notice boards of Maastricht University and in local newspapers. Subjects underwent a medical screening and all were in good health, were non-smokers, did not use medication (except for contraceptives), did not have a cow milk allergy and were at most moderate alcohol users. Nine subjects did not complete the weight loss period due to inability to comply with the diet or for personal reasons. From the 72 subjects who finished the weight loss period, 65 subjects started the weight maintenance period after a weight loss of $6 \pm 2 \%$ of initial body weight. Subjects signed an informed consent before participating in the study. The study protocol was approved by the Medical Ethical Committee of the Maastricht University Medical Centre.

\subsection{Experimental design}

The study had a single blind parallel design. Subjects were randomly assigned to one of three treatment groups: 1) sustained milk protein diet (SMP, control group 1), 2) supra-sustained milk protein diet (SSMP, control group 2), 3) supra-sustained gelatin-milk protein diet (GMP, intervention group). After following an 8-week weight loss period, based on an energy intake of $33 \%$ of individual energy re- quirements, subjects started a 4-month weight maintenance period. Subjects visited the university for measurements at the end of week 8 , after 2 months (end week 16) and after 4 months (end week 24) of the weight maintenance period.

\subsection{Energy intake}

During the complete weight maintenance period (weeks 9-24) subjects from all 3 diet groups consumed a diet that was 100\% of their individual energy requirements for energy balance. This was calculated as $67 \%$ from $100 \%$ of energy requirements at the start of the weight loss period. The energy content of the diet at the start of the weight loss period was based on subject-specific average daily energy requirements and calculated as the Basal Metabolic Rate (BMR) multiplied with a Physical Activity Level (PAL) of 1.5. BMR was calculated with the Harris-Benedict formula [24].

\subsection{Diets}

During the complete 4-months weight maintenance period subjects from all 3 diet groups consumed a fixed amount of protein each day, referred to as (supra-)sustained protein diets. This implied that the absolute protein content of each of the three protein diets remained the same during the whole period. During the first 2 months of weight maintenance, the complete diet (100\% of energy requirements) was provided. During the last 2 months of weight maintenance half of the diet ( $50 \%$ of energy requirements) was provided, while subjects were able to eat ad libitum, without counselling of the research team, for the other 50\% of energy requirements. To keep protein intake the same during the complete weight maintenance period, each diet differed in percentage of energy from protein between weeks 9-16 and weeks 17-24 (Table 1). The protein content of the two supra-sustained protein diets was twice the amount of the sustained protein diet. Carbohydrate content was kept similar between the 3 diet groups in order to prevent a possible effect from carbohydrate, as ingestion of this nutrient results in insulin secretion, and insulin is involved in protein metabolism [25]. All 3 diets were provided as meal replacements and contained all necessary vitamins, minerals, fatty acids and carbohydrates. The protein content of the sustained and supra-sustained milk protein diets consisted of $100 \%$ milk protein, while the protein content of the supra-sustained gelatin-milk protein diet consisted of $50 \%$ milk protein and $50 \%$ gelatin. In addition, subjects were instructed to eat four portions of fruit and vegetables each day and drink at least $1.5 \mathrm{~L}$ of water.

\subsubsection{Compliance with protein intake}

Before every test day subjects collected their urine for $24 \mathrm{~h}$, which was analyzed for nitrogen to check the compliance with protein intake. Protein intake was calculated from the $24 \mathrm{~h}$ nitrogen output as follows: protein intake $(\mathrm{g} / \mathrm{d})=$ nitrogen output in $24 \mathrm{~h}$ urine $(\mathrm{g} / \mathrm{d}) \times 6.25$.

\section{Table 1}

Macronutrient compositions of the SMP, SSMP and GMP diets during weeks 9-16 and weeks 17-24 of the weight maintenance period.

\begin{tabular}{|c|c|c|c|c|c|c|}
\hline & \multicolumn{3}{|c|}{$\begin{array}{l}\text { Weeks 9-16: } 100 \% \text { of } \\
\text { energy requirements }\end{array}$} & \multicolumn{3}{|c|}{$\begin{array}{l}\text { Weeks } 17-24: 50 \% \text { of } \\
\text { energy requirements } \\
\text { ( }+ \text { ad libitum) }\end{array}$} \\
\hline & SMP & SSMP & GMP & SMP & SSMP & GMP \\
\hline Milk protein (En\%) & 15 & 30 & 15 & 30 & 60 & 30 \\
\hline Gelatin (En\%) & & & 15 & & & 30 \\
\hline Fat (En\%) & 40 & 25 & 25 & 35 & 5 & 5 \\
\hline Carbohydrate (En\%) & 45 & 45 & 45 & 35 & 35 & 35 \\
\hline
\end{tabular}

Abbreviations: En\% = \% of energy; GMP = supra-sustained gelatin-milk protein diet; $\mathrm{SMP}=$ sustained milk protein diet; SSMP $=$ supra-sustained milk protein diet 


\subsection{Measurements}

Subjects visited the university for the following measurements at the end of week 8, after 2 months (end week 16) and after 4 months (end week 24) of the weight maintenance period. Subjects came to the university in the morning, after an overnight fast, and were not allowed to eat and drink until all measurements were finished.

\subsubsection{Body weight and height}

BW was measured on a digital scale (BOD POD, Life Measurement Inc., CA, USA) with subjects in their underwear, in a fasted state and after voiding their bladder. Height was measured using a wallmounted stadiometer (Seca, Model 225, Hamburg, Germany). BMI was calculated as BW divided by height ${ }^{2}\left(\mathrm{~kg} / \mathrm{m}^{2}\right)$.

\subsubsection{Waist and hip circumference}

Waist circumference was measured at the site of the smallest circumference between the rib cage and the ileac crest, with subjects in standing position. Hip circumference was measured at the site of the largest circumference between the waist and the thighs. Both waist and hip circumferences were measured with an accuracy of 1.0 $\mathrm{mm}$. The waist:hip ratio was calculated by dividing the waist circumference by the hip circumference.

\subsubsection{Body composition}

Body composition was determined according to the 3-compartment model based on BW, body volume as measured with the air displacement plethysmograph [26], and total body water as measured with the deuterium dilution $\left({ }^{2} \mathrm{H}_{2} \mathrm{O}\right)$ technique $[27,28]$, and was calculated by using the combined equation of Siri [29].

\subsubsection{Resting energy expenditure (REE) and RQ}

REE was measured by means of an open-circuit ventilated hood system, while subjects were lying supine for $40 \mathrm{~min}$. Gas analyses were performed by a paramagnetic oxygen analyzer (Servomex, type 500A, Crowborough, Sussex, UK) and an infrared carbon dioxide analyzer (Servomex, type 500A, Crowborough, Sussex, UK). Calculation of REE was based upon Weir's formula [30]. RQ was calculated as $\mathrm{CO}_{2}$ produced $/ \mathrm{O}_{2}$ consumed. This measurement was not performed at week 24 .

\subsubsection{Blood pressure and heart rate}

Diastolic and systolic blood pressure, and heart rate were measured with an upper arm digital blood pressure monitor (OMRON M6, Omron Healthcare Europe BV, Hoofddorp, The Netherlands) while subjects were sitting quietly in a chair.

\subsubsection{Eating behavior}

The Dutch translation of the Three Factor Eating Questionnaire (TFEQ) [31] was used to determine if attitude towards food intake changed during the weight loss period. The first factor of the TFEQ (F1) measures cognitive restrained eating: control of food intake by thought and will-power. The second factor (F2) represents disinhibition: an incidental inability to resist eating cues, or inhibition of dietary restraint, and emotional eating. The third factor (F3) examines the subjective feeling of general hunger.

\subsubsection{Physical activity}

To determine if physical activity was kept constant during the weight maintenance period, subjects filled in the Baecke questionnaire [32]. From this questionnaire 1) physical activity at work, 2) sport during leisure time, and 3) physical activity during leisure time excluding sport, could be determined.

\subsubsection{Postabsorptive appetite profile}

In the morning, after an overnight fast, appetite was scored by $100 \mathrm{~mm}$ anchored Visual Analogue Scales (VAS). Four questions were asked, anchored with 'not at all' to 'extremely', namely "How satiated do you feel?", "How full do you feel?", "How hungry are you?", and "How is your desire to eat?".

\subsubsection{Blood parameters}

Fasting blood samples were taken for measurements of plasma glucagon-like peptide-1 (GLP-1), peptide-tyrosine-tyrosine (PYY), insulin, glucose, creatinine (serum), high-density lipoprotein (HDL), low-density lipoprotein (LDL), triacylglycerol (TAG) and free fatty acid (FFA) concentrations. The blood for GLP-1 was collected into EDTA-containing tubes to which dipeptidyl peptidase IV inhibitor $(10 \mu \mathrm{L} / \mathrm{mL}$ blood) was added. For PYY analysis, blood was collected into EDTA-containing tubes in which dipeptidyl peptidase IV inhibitor $(10 \mu \mathrm{L} / \mathrm{mL}$ blood) and aprotinin ( $500 \mathrm{KIU} / \mathrm{mL}$ blood) was added. The blood for insulin, glucose, HDL, LDL, TAG and FFA was collected into EDTA-containing tubes. The blood for creatinine was collected in serum separator tubes. After the collection of blood into the tubes, blood samples were immediately centrifuged for $10 \mathrm{~min}$ (3000 rpm at $4{ }^{\circ} \mathrm{C}$ ), except for the creatinine tube, which was centrifuged after being kept $60 \mathrm{~min}$ at room temperature. Plasma and serum samples were immediately frozen in liquid nitrogen and stored at $-80^{\circ} \mathrm{C}$ until analyzed further. Plasma active GLP-1 concentrations were analyzed by enzyme-linked immunosorbent assay (EGLP-35K; Linco Research Inc, St Charles, MO). Plasma concentrations of PYY and insulin were measured by radioimmunoassay (Linco Research Inc, St Charles, MO). Plasma glucose concentrations were determined by using the hexokinase method (Glucose HK CP kit; ABX diagnostics, Montpellier, France). The HOMA index was calculated as (fasting glucose [mmol/ $\mathrm{L}] \times$ fasting insulin $[\mathrm{microU} / \mathrm{mL}]) / 22.5$. Serum creatinine concentrations were analyzed by means of the Jaffe rate method on the Synchron LX20 Pro (Beckman Coulter, Nyon, Switzerland). Plasma total cholesterol and HDL concentrations were analyzed using CHODPAP reagent (Roche Diagnostics GmbH, Mannheim, Germany). LDL was calculated using the Friedewald formula [33]. Plasma TAG concentrations were analyzed with the GPO-Trinder kit (Sigma, Missouri, USA). Plasma FFA concentrations were analyzed by using the ACSACOD-MEHA method in the Wako-NEFA-C kit (Wako Chemicals $\mathrm{GmbH}$, Neuss, Germany). No blood measurements were performed at week 24

\subsection{Statistical analysis}

Data are presented as mean \pm standard deviation (SD), unless otherwise indicated. For each diet group, a repeated-measures ANOVA was carried out for determination of possible differences between week 8 and week 16, and between week 16 and week 24 in all measured parameters. To determine possible differences between the supra-sustained gelatin-milk protein diet group and the two control diet groups, a factorial ANOVA was carried out. Post-hoc analyses were made with Fisher's PLSD. To determine relationships between variables, simple linear regression analyses were performed. The level of statistical significance was set at $P<0.05$. Statistical analyses were performed by using StatView 5.0 (SAS Institute Inc., Cary, NC).

\section{Results}

Subject characteristics for the 3 diet groups at the start of the weight maintenance period are presented in Table 2 .

\subsection{Compliance to the diets}

A good compliance was reached during the complete weight maintenance period. At weeks 8 and 16 the daily protein intake (DPI) was significantly higher in both supra-sustained protein diet groups compared with the sustained milk protein diet group (Table 2). 
Table 2

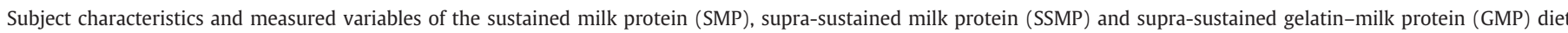
groups at the start, at week 16 , and at the end of weight maintenance.

\begin{tabular}{|c|c|c|c|c|c|c|c|c|c|}
\hline & \multicolumn{3}{|l|}{ SMP } & \multicolumn{3}{|l|}{$\underline{\text { SSMP }}$} & \multicolumn{3}{|l|}{$\underline{\text { GMP }}$} \\
\hline & Week 8 & Week 16 & Week 24 & Week 8 & Week 16 & Week 24 & Week 8 & Week 16 & Week 24 \\
\hline$N(\mathrm{M} / \mathrm{F})$ & $26(4 / 22)$ & - & - & $19(6 / 13)$ & - & - & $20(5 / 15)$ & - & - \\
\hline Age (year) & $43 \pm 11$ & - & - & $43 \pm 10$ & - & - & $44 \pm 10$ & - & - \\
\hline Height (m) & $1.67 \pm 0.06$ & - & - & $1.74 \pm 0.07$ & - & - & $1.67 \pm 0.12$ & - & - \\
\hline DPI (g/kg per day) & $0.77 \pm 0.23$ & $0.78 \pm 0.27$ & $0.97 \pm 0.39$ & $1.15 \pm 0.32^{\mathrm{a}}$ & $1.16 \pm 0.25^{\mathrm{a}}$ & $1.31 \pm 0.37^{\mathrm{a}}$ & $1.17 \pm 0.48^{\mathrm{a}}$ & $1.21 \pm 0.43^{\mathrm{a}}$ & $1.26 \pm 0.67$ \\
\hline Waist:hip ratio"\# & $0.89 \pm 0.05$ & $0.87 \pm 0.06^{\mathrm{b}}$ & $0.87 \pm 0.06$ & $0.90 \pm 0.07$ & $0.89 \pm 0.07$ & $0.90 \pm 0.07$ & $0.91 \pm 0.05$ & $0.88 \pm 0.07^{\mathrm{b}}$ & $0.88 \pm 0.07$ \\
\hline $\mathrm{RQ}^{\#}$ & $0.81 \pm 0.03$ & $0.84 \pm 0.04^{\mathrm{b}}$ & - & $0.80 \pm 0.03$ & $0.83 \pm 0.05^{\mathrm{b}}$ & - & $0.82 \pm 0.03$ & $0.83 \pm 0.05$ & - \\
\hline Diastole $^{\#}$ (mmHg) & $75 \pm 9$ & $77 \pm 9$ & $75 \pm 9$ & $72 \pm 9$ & $74 \pm 7$ & $74 \pm 7$ & $75 \pm 11$ & $75 \pm 12$ & $72 \pm 11$ \\
\hline Systole $^{\#}$ (mmHg) & $118 \pm 10$ & $120 \pm 13$ & $118 \pm 12$ & $116 \pm 11$ & $117 \pm 10$ & $119 \pm 9$ & $116 \pm 14$ & $118 \pm 15$ & $116 \pm 15$ \\
\hline Heart rate" (beats/min) & $64 \pm 9$ & $65 \pm 10$ & $69 \pm 8^{c}$ & $64 \pm 8$ & $66 \pm 8$ & $71 \pm 10^{c}$ & $66 \pm 10$ & $65 \pm 10$ & $71 \pm 11^{\mathrm{c}}$ \\
\hline 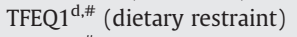 & $11 \pm 5$ & $11 \pm 5$ & $12 \pm 5$ & $11 \pm 4$ & $12 \pm 4$ & $12 \pm 5$ & $12 \pm 5$ & $12 \pm 4$ & $12 \pm 5$ \\
\hline TFEQ2 $^{\text {e,\# }}$ (disinhibition) & $5 \pm 2$ & $5 \pm 2$ & $4 \pm 2$ & $5 \pm 3$ & $5 \pm 3$ & $5 \pm 3$ & $5 \pm 3$ & $4 \pm 2$ & $5 \pm 2$ \\
\hline TFEQ3 $^{\text {f,\# }}$ (hunger) & $3 \pm 3$ & $3 \pm 2$ & $3 \pm 3$ & $4 \pm 3$ & $3 \pm 2$ & $3 \pm 2$ & $3 \pm 3$ & $2 \pm 2$ & $3 \pm 4$ \\
\hline Baecke $^{\#}$ (work) & $2.77 \pm 0.53$ & $2.69 \pm 0.58$ & $2.70 \pm 0.58$ & $2.55 \pm 0.62$ & $2.56 \pm 0.62$ & $2.55 \pm 0.63$ & $2.90 \pm 0.49$ & $2.85 \pm 0.47$ & $2.90 \pm 0.46$ \\
\hline Baecke $^{\#}$ (sport) & $2.69 \pm 0.91$ & $2.66 \pm 1.00$ & $2.40 \pm 0.93$ & $2.63 \pm 0.82$ & $2.67 \pm 0.82$ & $2.58 \pm 0.73$ & $2.69 \pm 0.91$ & $2.62 \pm 0.96$ & $2.57 \pm 0.79$ \\
\hline Baecke $^{\#}$ (leisure) & $3.17 \pm 0.63$ & $3.19 \pm 0.56$ & $3.33 \pm 0.65$ & $3.07 \pm 0.67$ & $3.05 \pm 0.60$ & $2.96 \pm 0.55$ & $3.16 \pm 0.56$ & $3.19 \pm 0.64$ & $3.18 \pm 0.68$ \\
\hline Baecke $^{\#}$ (total) & $8.63 \pm 1.36$ & $8.54 \pm 1.43$ & $8.44 \pm 1.49$ & $8.25 \pm 1.45$ & $8.28 \pm 1.47$ & $8.09 \pm 1.42$ & $8.74 \pm 1.48$ & $8.66 \pm 1.34$ & $8.65 \pm 1.30$ \\
\hline VAS $^{\#}$ (satiety) & $44 \pm 16$ & $46 \pm 16$ & $46 \pm 21$ & $39 \pm 23$ & $40 \pm 16$ & $40 \pm 20$ & $37 \pm 16$ & $38 \pm 17$ & $40 \pm 20$ \\
\hline VAS $^{\#}$ (fullness) & $43 \pm 16$ & $47 \pm 12$ & $49 \pm 17$ & $41 \pm 23$ & $37 \pm 18$ & $40 \pm 13$ & $34 \pm 14$ & $32 \pm 14$ & $42 \pm 22$ \\
\hline VAS $^{\#}$ (hunger) & $33 \pm 17$ & $35 \pm 17$ & $28 \pm 18$ & $25 \pm 19$ & $26 \pm 18$ & $32 \pm 17$ & $34 \pm 20$ & $33 \pm 18$ & $34 \pm 20$ \\
\hline VAS $^{\#}$ (desire to eat) & $37 \pm 19$ & $39 \pm 15$ & $33 \pm 20$ & $24 \pm 17$ & $30 \pm 21$ & $36 \pm 25$ & $37 \pm 19$ & $38 \pm 21$ & $39 \pm 22$ \\
\hline
\end{tabular}

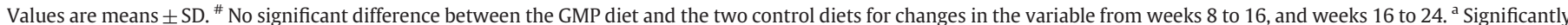

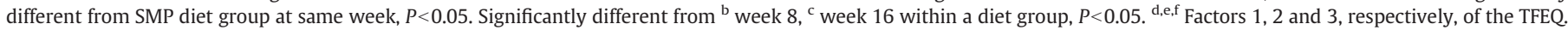

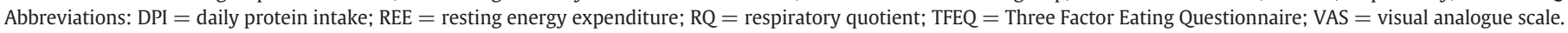

During the last 2 months of the weight maintenance period, when subjects were allowed to eat ad libitum in addition, protein intake increased in all 3 diet groups, indicating a good compliance during this period.

\subsection{Body weight and BMI}

At the end of the complete 4-month weight maintenance period, no significant weight regain occurred in all 3 diet groups. Weight loss at week 8 was $-6.1 \pm 2.2 \mathrm{~kg},-5.3 \pm 1.5$, and $-4.7 \pm 1.5 \mathrm{~kg}$ in the SMP, SSMP and GMP diet groups respectively, while weight loss at week 24 was $-7.5 \pm 5.3 \mathrm{~kg},-6.4 \pm 2.6$, and $-4.5 \pm 3.3 \mathrm{~kg}$ respectively. In all 3 diet groups BW and BMI significantly decreased from weeks 8 to 16 (Fig. $1, P<0.05$ ); after that BW and BMI were sustained. The changes in BW and BMI were similar between the GMP diet group and both control groups during the first 2 months and during the last 2 months of the weight maintenance period. Moreover, the changes between the SMP and SSMP group were similar.

\subsection{Waist:hip ratio}

Waist:hip ratio significantly decreased from weeks 8 to 16 in the SMP and GMP diet group $(P<0.05$, Table 2$)$, and remained the same from weeks 16 to 24 in all 3 diet groups. The changes in waist:hip ratio were similar between the GMP diet group and both control groups during the first 2 months and during the last 2 months of the weight maintenance period.

\subsection{Body composition}

Fat free mass (FFM) in kg did not significantly change from weeks 8 to 16, and from weeks 16 to 24, in all 3 diet groups (Fig. 2a). FFM\% significantly increased, and fat mass (FM) in $\mathrm{kg}$ and expressed as \% of BW were significantly decreased from weeks 8 to 16 in all 3 diet groups $(P<0.05$, Fig. $2 \mathrm{~b}-\mathrm{d})$, while sustained from week 16 to week 24 . The changes in FFM ( $\mathrm{kg}$ or \%) and FM ( $\mathrm{kg}$ or \%) were similar between the GMP diet group and both control groups during the first 2 months and during the last 2 months of the weight maintenance period.

Post-hoc comparisons between the SMP and SSMP diets show that the decrease in body mass and fat mass over time is similar, yet fat free
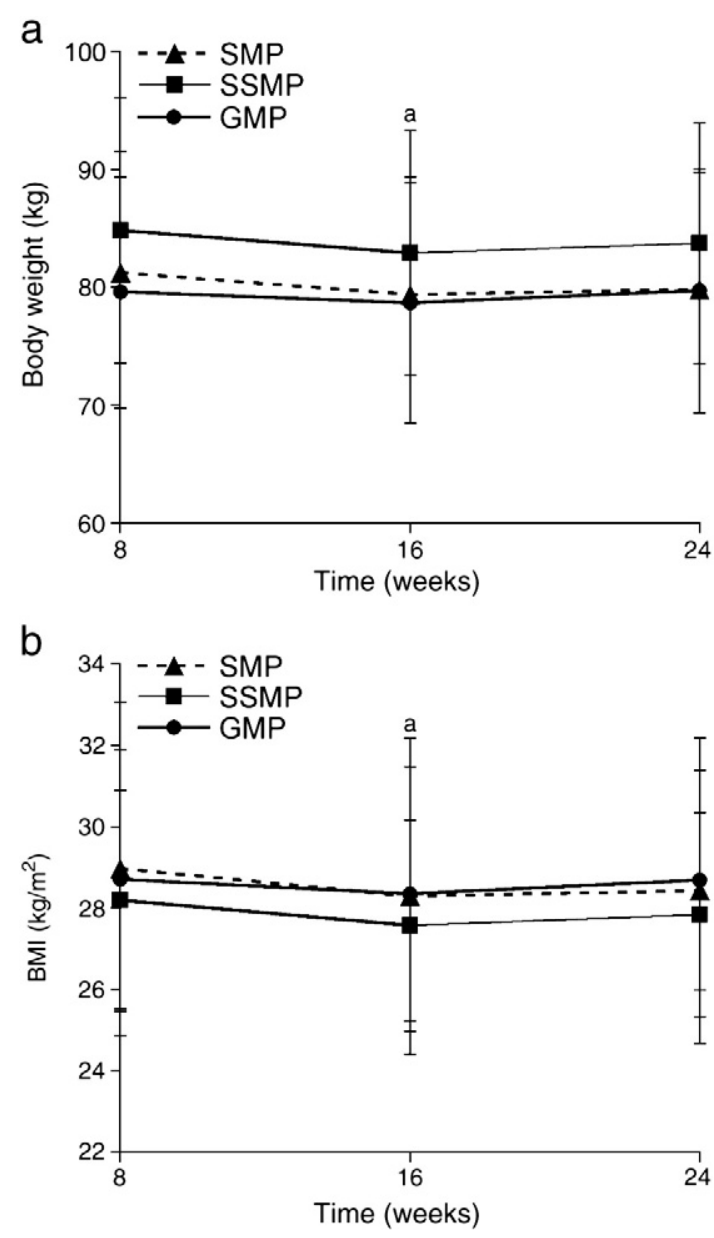

Fig. 1. Body weight (a) and body mass index (BMI) (b) for the sustained milk protein (SMP), supra-sustained milk protein (SSMP) and supra-sustained gelatin-milk protein (GMP) diet group before (week 8), during (week 16) and after (week 24) the weight maintenance period. Values are means \pm SD. ${ }^{a}$ Significantly different from week 8 for all 3 diet groups, $P<0.05$. Changes in body weight and BMI from week 8 to week 16 , and from week 16 to week 24, were not significantly different between the GMP diet and the two control diets. 
a

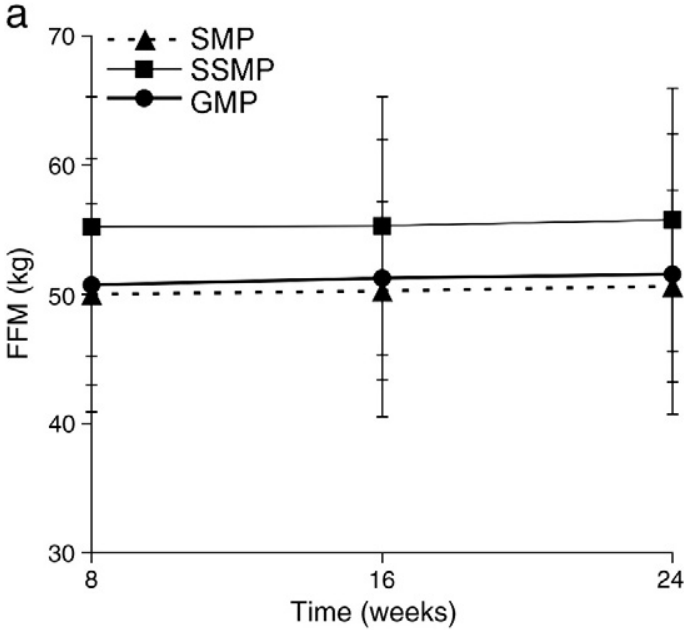

C

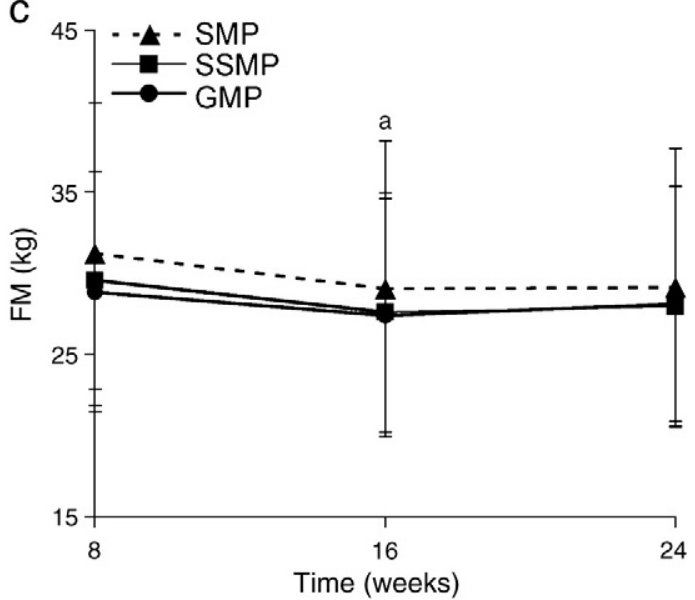

b

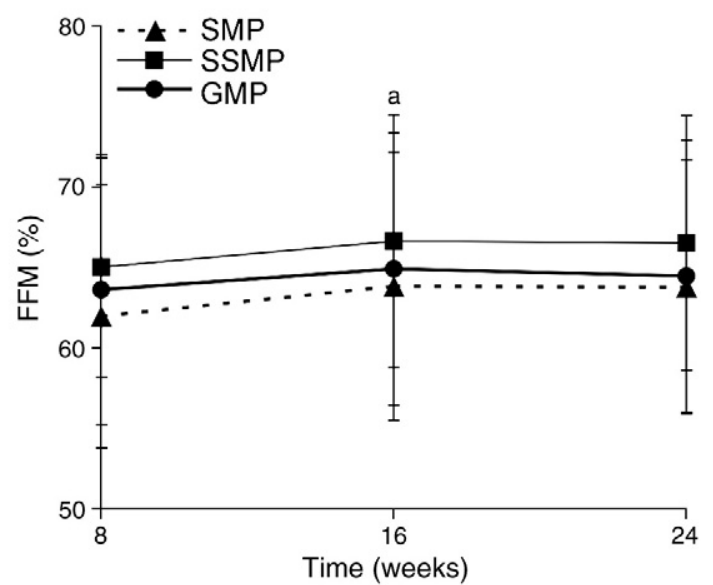

d

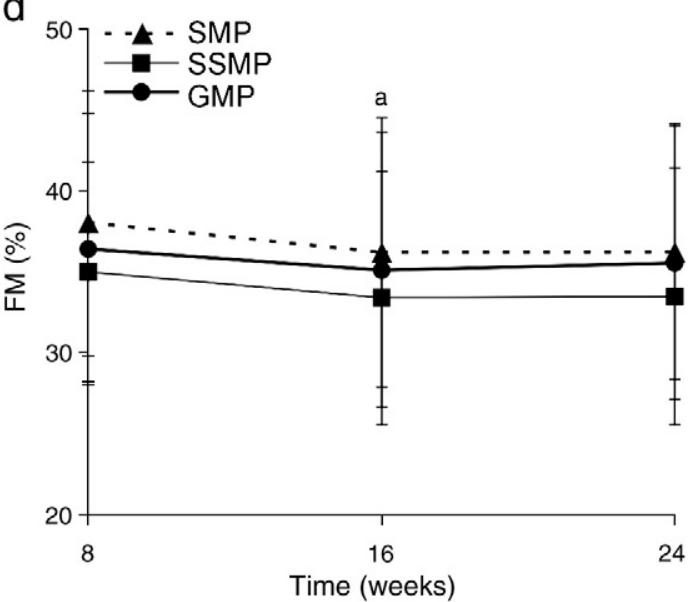

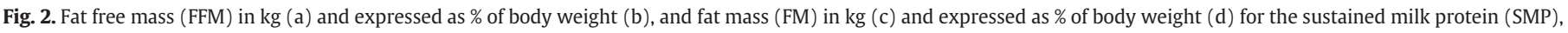

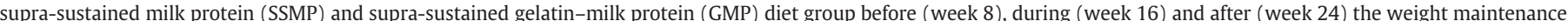

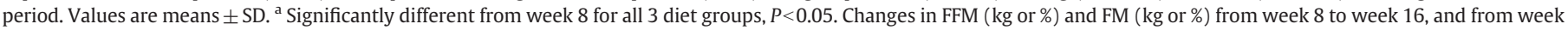
16 to week 24 , were not significantly different between the GMP diet and the two control diets.

mass did not decrease in the SSMP group, but slightly decreased in the SP group. Since the research is part of a larger study, that part is submitted elsewhere by Soenen et al.

\section{5. $R Q$}

RQ significantly increased from weeks 8 to 16 in the SMP and SSMP diet group $(P<0.05$, Table 2$)$, and changes in RQ were similar between the GMP diet group and both control groups.

\subsection{REE as a function of FFM}

REE is plotted as a function of fat free mass at the start (week 8) and after 2 months of the weight maintenance period (week 16) for the SMP (Fig. 3a), SSMP (Fig. 3b) and GMP (Fig. 3c) diet groups. In all 3 diet groups a significant linear relation was present between REE $(\mathrm{MJ} / \mathrm{d})$ and FFM $(\mathrm{kg})$ at week 8 and week $16(P<0.0001)$. To determine for each diet group if REE as function of FFM changed significantly over time, as shown by the regression lines at week 8 and week 16, the FFM $(\mathrm{kg})$ values from week 16 were filled in the slope equation of week 8 to obtain a calculated REE of week 16. The calculated and measured REE of week 16 were analyzed with ANOVA repeated-measures to determine any changes in REE as function of FFM. In all 3 diet groups, REE as a function of FFM appeared not to have changed significantly from weeks 8 to 16 , and possible small but not significant differences in these relationships did not differ between the GMP diet and both control diet groups.

Similarly, REE as a function of fat free mass did not decrease in the SSMP group, but decreased slightly in the SMP group after 4 months. Since the research is part of a larger study, that part is submitted elsewhere by Soenen et al.

\subsection{Blood pressure and heart rate}

Diastole and systole were similar between weeks 8 and 16, and weeks 16 and 24 in all 3 diet groups (Table 2). Heart rate was similar between weeks 8 and 16, and significantly increased from weeks 16 to $24(P<0.05)$ in all 3 diet groups (Table 2$)$. The changes in blood pressure and heart rate were similar between the GMP diet group and both control groups during the first 2 months and during the last 2 months of the weight maintenance period.

\subsection{Eating behavior}

Dietary restraint (factor 1 of the TFEQ), disinhibition (factor 2) and hunger (factor 3 ) did not significantly change from weeks 8 to 16, and from weeks 16 to 24 in all 3 diet groups (Table 2). The changes in dietary restraint, disinhibition and hunger from weeks 8 to 16 and from weeks 16 to 24 were similar between the GMP diet group and both control groups. 

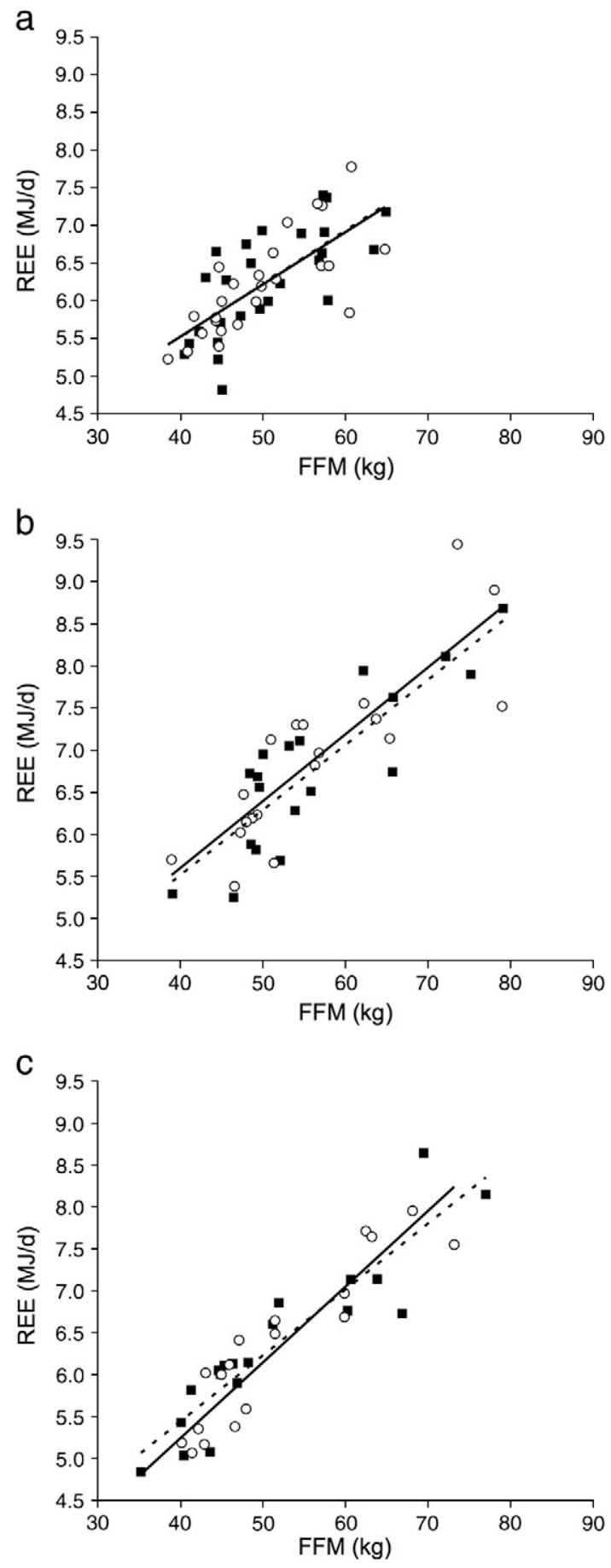

Fig. 3. Resting energy expenditure (REE) as a function of fat free mass (FFM) plotted for week 8 (start weight maintenance, $O$, trendline) and for week 16 (after 8 weeks of weight maintenance, $\mathbf{\square}$, trendline $\cdots$ ) for the sustained milk protein (SMP, a), suprasustained milk protein (SSMP, b) and supra-sustained gelatin-milk protein (GMP, c) diet groups. Regression equation SMP diet, week 8: $\mathrm{REE}=0.069 \mathrm{FFM}+2.747$ $\left(R^{2}=0.559, P<0.0001\right)$. Regression equation SMP diet, week $16: \mathrm{REE}=0.071 \mathrm{FFM}+$ $2.68\left(R^{2}=0.499, P<0.0001\right)$. Regression equation SSMP diet, week 8: REE $=0.079 \mathrm{FFM}+$ $2.425\left(R^{2}=0.717, P<0.0001\right)$. Regression equation SSMP diet, week 16: $R E E=$ 0.077 FFM $+2.42\left(R^{2}=0.740, P<0.0001\right)$. Regression equation GMP diet, week 8: $\mathrm{REE}=0.09 \mathrm{FFM}+1.631\left(R^{2}=0.864, P<0.0001\right)$. Regression equation GMP diet, week 16: $\mathrm{REE}=0.079 \mathrm{FFM}+2.292\left(R^{2}=0.838, P<0.0001\right)$.

\subsection{Physical activity}

Physical activity (Baecke Work, Sport, Leisure or Total, Table 2) did not significantly change from weeks 8 to 16 , and weeks 16 to 24 in all 3 diet groups. The changes in physical activity were similar between the GMP diet group and both control groups during the first 2 months and during the last 2 months of the weight maintenance period.

\subsection{Postabsorptive appetite profile}

Postabsorptive scores for satiety, fullness, hunger and desire to eat were similar between weeks 8 and 16, and weeks 16 and 24 in all 3 diet groups. The changes in these scores were similar between the GMP diet group and both control groups during the first 2 months and during the last 2 months of the weight maintenance period.

\subsection{Blood parameters}

Fasting blood concentrations were measured at weeks 8 and 16 (Table 3). Plasma GLP-1, PYY, insulin and TAG concentrations, serum creatinine concentrations and HOMA index did not significantly change from weeks 8 to 16 in all 3 diet groups. Plasma glucose concentrations significantly decreased in the GMP diet group $(P<0.05)$, and did not significantly change in the SMP and SSMP diet groups. Plasma HDL concentrations significantly increased in the GMP diet group $(P<0.05)$, and did not significantly change in the SMP and SSMP diet groups. Plasma LDL concentrations significantly increased in all 3 diet groups $(P<0.05)$. Plasma FFA concentrations significantly decreased in the SMP and GMP diet groups $(P<0.05)$, and did not significantly change in the SSMP diet group. The changes in all blood variables were similar between the GMP diet group and both control groups.

\section{Discussion}

In this study we investigated whether the addition of gelatin to a milk protein diet results in a better weight maintenance during a 4months weight maintenance period after weight loss. All 3 diets resulted in a successful weight maintenance period, as no weight was significantly regained after weight loss at the end of the 4-months weight maintenance period. No significant differences between the GMP diet group and the SMP and SSMP diet groups were observed in changes over the first and last 8 weeks of the weight maintenance period in BW, BMI, waist:hip ratio, body composition, RQ, REE as a function of FFM, blood pressure, heart rate, dietary restraint, disinhibition, subjective feeling of general hunger, physical activity, postabsorptive appetite profile, plasma/serum GLP-1, PYY, insulin, glucose, creatinine, HDL, LDL, TAG, and FFA concentrations, and HOMA index. For successful weight maintenance, a sustained milk protein diet is sufficient, while addition of gelatin has no additional effects on weight maintenance. Compliance in this study was confirmed with the $24 \mathrm{~h}$ urinary nitrogen results. The DPI of the sustained milk protein diet group at weeks 8 and 16 was $0.8 \mathrm{~g} / \mathrm{kg}$ per day, which is the required minimum amount of daily protein intake as recommended by the World Health Organization [34]. The DPI of the suprasustained protein diet groups, being $1.2 \mathrm{~g} / \mathrm{kg}$ per day at weeks 8 and 16 , were significantly higher compared with the sustained protein diet group, while protein intake was similar between both suprasustained protein diet groups. During the last 8 weeks of weight maintenance $50 \%$ of energy requirements was provided as a diet, which contained the same absolute amount of protein they had to consume during the first 8 weeks of weight maintenance. As subjects were allowed the eat ad libitum in addition, from the increases in protein intake in all 3 diet groups can be concluded that subjects were also compliant during the last 8 weeks of the weight maintenance period.

The beneficial short-term effect of gelatin on hunger suppression $[8,13]$ did not play a role in the long term during weight maintenance. As expected the hunger suppression effect of an incomplete protein had disappeared by adding the complete milk-protein to the gelatin in a sufficient amount, and the supposed gluconeogenesis did not 
Table 3

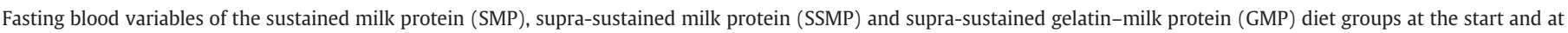
week 16 of weight maintenance ${ }^{\mathrm{a}}$.

\begin{tabular}{|c|c|c|c|c|c|c|}
\hline & \multicolumn{2}{|l|}{ SMP } & \multicolumn{2}{|l|}{ SSMP } & \multicolumn{2}{|l|}{ GMP } \\
\hline & Week 8 & Week 16 & Week 8 & Week 16 & Week 8 & Week 16 \\
\hline GLP-1 (pmol/L) & $1.3 \pm 0.9$ & $1.5 \pm 1.3$ & $2.1 \pm 2.2$ & $1.9 \pm 2.2$ & $1.3 \pm 0.7$ & $1.3 \pm 0.7$ \\
\hline PYY (pg/mL) & $19 \pm 11$ & $16 \pm 16$ & $17 \pm 17$ & $15 \pm 9$ & $18 \pm 18$ & $25 \pm 30$ \\
\hline Insulin $(\mu \mathrm{U} / \mathrm{mL})$ & $11.31 \pm 3.92$ & $11.03 \pm 3.84$ & $9.84 \pm 3.91$ & $10.51 \pm 3.68$ & $10.31 \pm 4.31$ & $10.31 \pm 3.08$ \\
\hline Glucose (mmol/L) & $5.10 \pm 0.51$ & $4.99 \pm 0.35$ & $5.13 \pm 0.48$ & $5.08 \pm 0.41$ & $5.21 \pm 0.52$ & $4.94 \pm 0.34^{b}$ \\
\hline HOMA index & $2.60 \pm 1.06$ & $2.47 \pm 0.98$ & $2.27 \pm 1.06$ & $2.40 \pm 0.94$ & $2.41 \pm 1.08$ & $2.27 \pm 0.68$ \\
\hline Creatinine $(\mu \mathrm{mol} / \mathrm{L})$ & $83 \pm 16$ & $84 \pm 21$ & $83 \pm 16$ & $75 \pm 13$ & $82 \pm 15$ & $83 \pm 21$ \\
\hline $\mathrm{HDL}(\mathrm{mmol} / \mathrm{L})$ & $1.36 \pm 0.34$ & $1.41 \pm 0.40$ & $1.30 \pm 0.22$ & $1.36 \pm 0.28$ & $1.38 \pm 0.29$ & $1.45 \pm 0.32^{b}$ \\
\hline $\mathrm{LDL}(\mathrm{mmol} / \mathrm{L})$ & $2.91 \pm 0.59$ & $3.26 \pm 0.82^{b}$ & $2.93 \pm 0.99$ & $3.44 \pm 0.73^{b}$ & $3.05 \pm 0.75$ & $3.39 \pm 0.85^{b}$ \\
\hline TAG $(\mathrm{mmol} / \mathrm{L})$ & $1.15 \pm 0.33$ & $1.29 \pm 0.45$ & $1.00 \pm 0.29$ & $1.10 \pm 0.29$ & $1.06 \pm 0.27$ & $1.09 \pm 0.31$ \\
\hline $\mathrm{FFA}(\mathrm{mmol} / \mathrm{L})$ & $576 \pm 198$ & $440 \pm 150^{b}$ & $542 \pm 154$ & $476 \pm 115$ & $514 \pm 164$ & $410 \pm 166^{\mathrm{b}}$ \\
\hline
\end{tabular}

Values are means $\pm \mathrm{SD}$

a No significant difference in change over time between the GMP diet and the two control diets in all variables.

b Significantly different from week 8 within a diet group, $P<0.05$.

support appetite homeostasis in a way that satiety would be increased [19-22]. This was confirmed by the postabsorptive appetite profiles and fasting plasma concentrations of the so-called satiety hormones GLP-1 and PYY. These variables did not significantly change over time and were not different between the GMP diet and both control diets. In addition, no significant changes in dietary restraint, disinhibition and general feelings of hunger as determined by the TFEQ were observed over time in all 3 diet groups, and as these changes over time were not different between the GMP diet and both control diets they could not have contributed to possible differences in weight change during this period. In all 3 diet groups the decrease in body weight from weeks 8 to 16 was the result of a loss in absolute fat mass, while absolute fat free mass did not change. This resulted in an improved body composition, as in all 3 diet groups FFM\% increased, and FM\% decreased. From weeks 16 to 24 the improved body composition was maintained in all 3 diet groups. No changes in FFM (kg or \%) and FM ( $\mathrm{kg}$ or \%) were observed in all 3 diet groups. As physical activity did not change over time in all 3 diet groups, physical activity was not involved in the improvement in body composition due to sparing of fat free mass. Although from weeks 8 to 16 , protein intake was 0.43 and $0.05 \mathrm{~g} / \mathrm{kg}$ per day higher in the GMP diet group compared with the SMP and SSMP diet groups, this did not result in a higher preservation of fat free mass. Thus, the addition of gelatin to a sustained milk protein diet, or the exchange of energy from milk protein with energy from gelatin in a supra-sustained protein diet did not affect body composition differently. Accordingly, resting energy expenditure as a function of fat free mass did not change from weeks 8 to 16 in all 3 diet groups. In addition, changes in RQ over time were not different between the GMP diet group and both milk protein diet groups. Although we focus here on the effect of the additional gelatin to the diet, the question on possible differences between the SMP and SSMP diets also is relevant. Post-hoc comparisons between those diets show that the decrease in body mass and fat mass over time is similar, yet fat free mass did not decrease in the SSMP group, but slightly decreased in the SP group. It appears that once subjects keep a sustained milk protein diet at the level of $0.8 \mathrm{~g}$ protein $/ \mathrm{kg}$ body mass intake, the main effect on body weight is reached. The SSMP diet only adds to this by sparing more fat free mass resulting in a better body composition. Accordingly REE as a function of fat free mass is preserved in that group throughout the phases.

Regarding health benefits, during the first 8 weeks of the weight maintenance period beneficial reductions in waist:hip ratio and FFA were observed. Although after weight loss plasma LDL concentrations were decreased [35], from weeks 8 to 16 of weight maintenance nonfavourable increases in plasma LDL concentrations were observed in all 3 diet groups. The beneficial decreases in diastole, systole and heart rate after weight loss [35] were maintained throughout the 4 months weight maintenance period, except from an increase in heart rate during the last 8 weeks of weight maintenance in all 3 diet groups.

In summary, this study shows that effects of a diet observed in the short-term do not necessarily result in similar effects in the long term, partly because it was not possible to give just gelatin as a protein over the long term, partly because the possible additional effect due to additional gelatin intake, namely gluconeogenesis, did not support body weight maintenance in a distinguishable way. The new aspect of this study was that the supposition that additional gelatin used in the long term could have a weak effect was ruled out.

We conclude that a supra-sustained gelatin-milk protein diet did not induce more beneficial effects on body weight maintenance and related variables during a 4 -months weight maintenance period after weight loss compared with a sustained and supra-sustained milk protein diet.

\section{Acknowledgment}

The research was supported by Top Institute Food and Nutrition, Wageningen, the Netherlands.

\section{References}

[1] Wilborn C, Beckham J, Campbell B, Harvey T, Galbreath M, La Bounty P, et al. Obesity: prevalence, theories, medical consequences, management, and research directions. J Int Soc Sports Nutr 2005;2:4-31.

[2] Halton TL, Hu FB. The effects of high protein diets on thermogenesis, satiety and weight loss: a critical review. J Am Coll Nutr 2004 Oct;23(5):373-85.

[3] Paddon-Jones D, Westman E, Mattes RD, Wolfe RR, Astrup A, WesterterpPlantenga M. Protein, weight management, and satiety. Am J Clin Nutr 2008 May;87(5):1558S-61S.

[4] Westerterp-Plantenga MS. Protein intake and energy balance. Regul Pept 2008 Aug 7;149(1-3):67-9.

[5] Westerterp-Plantenga MS, Lejeune MP. Protein intake and body-weight regulation. Appetite Oct 2005;45(2):187-90.

[6] Veldhorst MA, Nieuwenhuizen AG, Hochstenbach-Waelen A, Westerterp KR, Engelen MP, Brummer RJ, et al. Effects of complete whey-protein breakfasts versus whey without GMP-breakfasts on energy intake and satiety. Appetite 2009 Apr;52 (2):388-95.

[7] Veldhorst MA, Nieuwenhuizen AG, Hochstenbach-Waelen A, Westerterp KR, Engelen MP, Brummer RJ, et al. Effects of high and normal soy protein breakfasts on satiety and subsequent energy intake, including amino acid and 'satiety' hormone responses. Eur J Nutr 2009 Mar;48(2):92-100.

[8] Veldhorst MA Nieuwenhuizen AG, Hochstenbach-Waelen A, Westerterp KR Engelen MP, Brummer RJ, et al. A breakfast with alpha-lactalbumin, gelatin, or gelatin + TRP lowers energy intake at lunch compared with a breakfast with casein, soy, whey, or whey-GMP. Clin Nutr (Edinburgh, Scotland) Apr 2009;28(2): 147-55.

[9] Veldhorst MA, Nieuwenhuizen AG, Hochstenbach-Waelen A, Westerterp KR, Engelen MP, Brummer RJ, et al. Comparison of the effects of a high- and normalcasein breakfast on satiety, 'satiety' hormones, plasma amino acids and subsequent energy intake. Br J Nutr 2009 Feb;101(2):295-303. 
[10] Veldhorst MA, Nieuwenhuizen AG, Hochstenbach-Waelen A, van Vught AJ, Westerterp KR, Engelen MP, et al. Dose-dependent satiating effect of whey relative to casein or soy. Physiol Behav 2009 Mar 23;96(4-5):675-82.

[11] Nieuwenhuizen AG, Hochstenbach-Waelen A, Veldhorst MA, Westerterp KR Engelen MP, Brummer RJ, et al. Acute effects of breakfasts containing alphalactalbumin, or gelatin with or without added tryptophan, on hunger, 'satiety' hormones and amino acid profiles. Br J Nutr 2009 Jun;101(12):1859-66.

[12] Hochstenbach-Waelen A, Westerterp-Plantenga MS, Veldhorst MAB, Nieuwenhuizen AG, Westerterp KR. Comparison of 2 diets with either 25 or 10 energy\% gelatin on energy expenditure, substrate balances and appetite profile. e-SPEN. Eur e-J Clin Nutr Metab 2009;4:e329-36.

[13] Hochstenbach-Waelen A, Westerterp-Plantenga MS, Veldhorst MA, Westerterp KR. Single-protein casein and gelatin diets affect energy expenditure similarly but substrate balance and appetite differently in adults. J Nutr 2009 Dec;139(12): 2285-92.

[14] Hochstenbach-Waelen A, Veldhorst MA, Nieuwenhuizen AG, Westerterp-Plantenga MS, Westerterp KR. Comparison of 2 diets with either $25 \%$ or $10 \%$ of energy as casein on energy expenditure, substrate balance, and appetite profile. Am J Clin Nutr 2009 Mar;89(3):831-8.

[15] Gietzen DW, Hao S, Anthony TG. Mechanisms of food intake repression in indispensable amino acid deficiency. Annu Rev Nutr 2007;27:63-78.

[16] Hao S, Sharp JW, Ross-Inta CM, McDaniel BJ, Anthony TG, Wek RC, et al. Uncharged tRNA and sensing of amino acid deficiency in mammalian piriform cortex. Science (New York, NY) Mar 18 2005;307(5716):1776-8.

[17] Maurin AC, Jousse C, Averous J, Parry L, Bruhat A, Cherasse Y, et al. The GCN2 kinase biases feeding behavior to maintain amino acid homeostasis in omnivores. Cell Metab 2005 Apr;1(4):273-7.

[18] Towle HC. The metabolic sensor GCN2 branches out. Cell Metab 2007 Feb;5(2): 85-7.

[19] Harper AE, Benevenga NJ, Wohlhueter RM. Effects of ingestion of disproportionate amounts of amino acids. Physiol Rev 1970 Jul;50(3):428-558.

[20] Fromentin G, Feurte S, Nicolaidis S, Norgren R. Parabrachial lesions disrupt responses of rats to amino acid devoid diets, to protein-free diets, but not to highprotein diets. Physiol Behav Aug-Sep 2000;70(3-4):381-9.

[21] Gietzen DW, Rogers QR. Nutritional homeostasis and indispensable amino acid sensing: a new solution to an old puzzle. Trends Neurosci 2006 Feb;29(2):91-9.
[22] Carpenter KJ. A short history of nutritional science: part 1 (1785-1885). J Nutr 2003 Mar;133(3):638-45.

[23] Azzout B, Chanez M, Bois-Joyeux B, Peret J. Gluconeogenesis from dihydroxyacetone in rat hepatocytes during the shift from a low protein, high carbohydrate to a high protein, carbohydrate-free diet. J Nutr 1984 Nov;114(11):2167-78.

[24] Harris JA, Benedict FG. A biometric study of human basal metabolism. Proc Natl Acad Sci U S A 1918 Dec;4(12):370-3.

[25] Tesseraud S, Metayer S, Duchene S, Bigot K, Grizard J, Dupont J. Regulation of protein metabolism by insulin: value of different approaches and animal models. Domest Anim Endocrinol 2007 Aug;33(2):123-42.

[26] Hoffman CJ, Hildebrandt LA. Use of the air displacement plethysmograph to monitor body composition: a beneficial tool for dietitians. J Am Diet Assoc Sep 2001;101(9) 986, 8.

[27] Schoeller DA, van Santen E, Peterson DW, Dietz W, Jaspan J, Klein PD. Total body water measurement in humans with 180 and $2 \mathrm{H}$ labeled water. Am J Clin Nutr 1980 Dec;33(12):2686-93.

[28] van Marken Lichtenbelt WD Westerterp KR, Wouters L. Deuterium dilution as a method for determining total body water: effect of test protocol and sampling time. Br J Nutr Oct 1994;72(4):491-7.

[29] Siri WE. Body composition from fluid spaces and density: analysis of methods 1961. Nutrition Sep-Oct 1993;9(5):480-91 discussion, 92.

[30] Weir JB. New methods for calculating metabolic rate with special reference to protein metabolism. J Physiol 1949 Aug;109(1-2):1-9.

[31] Stunkard AJ, Messick S. The three-factor eating questionnaire to measure dietary restraint, disinhibition and hunger. J Psychosom Res 1985;29(1):71-83.

[32] Baecke JA, Burema J, Frijters JE. A short questionnaire for the measurement of habitual physical activity in epidemiological studies. Am J Clin Nutr 1982 Nov;36 (5):936-42.

[33] Friedewald WT, Levy RI, Fredrickson DS. Estimation of the concentration of lowdensity lipoprotein cholesterol in plasma, without use of the preparative ultracentrifuge. Clin Chem 1972 Jun;18(6):499-502.

[34] Protein and amino acid requirements in human nutrition. Report of a Joint WHO/ FAO/UNU Expert Consultation. Geneva; 2007. Report No.: 935.

[35] Hochstenbach-Waelen A, Westerterp KR, Soenen S, Westerterp-Plantenga MS, submitted for publication. Effects of a supra-sustained gelatin-milk protein diet compared with (supra-)sustained milk protein diets during weight loss. 